\title{
Farmers-Herdsmen Conflict in Africa: The Case of Nigeria
}

\author{
E.A. Oghuvbu', O.B. Oghuvbu² \\ ${ }^{1}$ Covenant University, Ota, Ogun State, Federal Republic of Nigeria \\ ${ }^{2}$ Delta State University, Abraka, Delta State, Federal Republic of Nigeria
}

\begin{abstract}
General population growth and an increase in the number of farmers, environmental degradation, disruption of conditions for resolving land and water disputes, and the proliferation of Small Arms and Light Weapons (SALW) in the Sahel and West Africa have exacerbated the struggle for the survival and security of economic livelihoods, and in particular negatively affected relationships between shepherds and farmers in several communities in Africa. This kind of conflict between farmers and herdsmen mainly applies to Nigeria, but is also present in other African countries, especially in Mali, Burkina Faso, Chad, Senegal, Cameroon, and Côte d'Ivoire. Such conflicts are not triggered by a single reason, but are driven by a set of multi-causal factors, such as scarce resources in the face of greater need, reprisal attacks, land and climate change, etc. Obviously, in case of Nigeria this kind of conflicts have a disintegrative impact, as they lead to the inimical effects to the country's unity. The need for fostering value reorientation and restoring earlier interactive ties between herdsmen and farmers seems vital today, so that Nigerians can learn to appreciate the values that unite them more than those that separate the society.
\end{abstract}

Key words: conflict, farmers, herdsmen, National unity, Nigeria

For citation: Oghuvbu, E.A. \& Oghuvbu, O.B. (2020). Farmers-Herdsmen Conflict in Africa: The Case of Nigeria. Vestnik RUDN. International Relations, 20 (4), 698-706. DOI: 10.22363/2313-0660-2020-20-4-698-706

\section{Конфликт фермеров и пастухов в Африке: пример Нигерии}

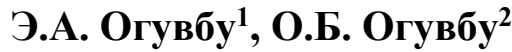 \\ ${ }^{1}$ Университет Ковенант, Ота, штат Огун, Нигерия \\ ${ }^{2}$ Государственный университет Дельты, Абрака, штат Дельта, Нигерия
}

Общий рост населения и увеличение числа фермеров, ухудшение экологической обстановки, отсутствие условий для разрешения земельных и водных споров, а также распространение стрелкового оружия и легких вооружений (СОЛВ) в Сахеле и Западной Африке обострили борьбу за выживание, породили новые угрозы экономической безопасности, а также усугубили конфликт между фермерами и пастухами в ряде стран Африки, в том числе Нигерии, Мали, Буркина-Фасо, Чаде, Сенегале, Камеруне и Кот-д’Ивуаре. Конфликт фермеров и пастухов рассмотрен на примере Нигерии, где он принял достаточно острые формы. В исследовании использовались вторичные данные, такие как статьи в научных журналах, проектные работы, газеты, онлайн-публикации и материалы государственных структур Нигерии. Анализ показал, что конфликты между фермерами и пастухами вызваны множественными причинами, такими как нехватка ресурсов, взаимные нападения, изменение состояния земли и климата и т. д. Выявлено, что такие конфликты оказывают разрушительное влияние на обстановку внутри государства и препятствуют единству страны. В связи с этим правительству Нигерии рекомендуется проводить политику, направленную на

(C) Oghuvbu E.A., Oghuvbu O.B., 2020

This work is licensed under a Creative Commons Attribution 4.0 International License.

https://creativecommons.org/licenses/by/4.0/ 
поощрение терпимости по отношению к другим этническим группам, а также восстановление прежних связей между пастухами и фермерами.

Ключевые слова: конфликт, фермеры, пастухи, национальное единство, Нигерия

Для цитирования: Oghuvbu E.A., Oghuvbu O.B. Farmers-Herdsmen Conflict in Africa: The Case of Nigeria // Вестник Российского университета дружбы народов. Серия: Международные отношения. 2020. Т. 20. № 4. C. 698 -706. DOI: $10.22363 / 2313-0660-2020-20-4-698-706$

\section{Introduction}

Peace in Nigeria is a crucial element needed for the co-existence and national unity, as it provides key function of the welfare of the state - to promote unity, non-violence, economic growth and human development. The menace of Fulani herdsmen in Nigeria makes the concept of peace sort of elusive. As rightly points out Muhammed, Ismaila and Bibi [2015] there is an increased rate of violence, kidnapping, insurgencies, vandalism, rape, unemployment, terrorist attacks, cultism, and arm robbery all over the world and Nigeria is not exempted in these global challenges. Mwanfupe adds that "farmers-herdsmen conflicts are equally prevalent in Cameroon, Tanzania, Sudan, Kenya, and not peculiar to only Nigeria" [Mwamfupe 2015: 3].

There have been numerous instances of farmers-herdsmen conflicts in Nigeria. These conflicts have now turn out to be heavily threatening Nigeria's national integration, the hitherto peaceful relationship between farmers and herdsmen throughout diverse components of Nigeria is degenerating to a carnage stage, leading to destruction of lives and properties [Muhammed, Ismaila, Bibi 2015]. Attempts of the federal government to curb the incessant farmer's herdsmen appear to be futile.

Nzeh [2015] asserts that before the present dangerous dimension of the conflict the relationship between farmers and herdsmen were quite cordial and symbiotic. He further posits that before herdsmen entry into Nigeria via the Nigeria / Cameroon border in search of pasture, the herdsmen settled in Borno / Adamawa where they found pasture. In these conditions the relationship with the farmers was peaceful by its nature, which was beneficial to both groups. In fact, the sufficiency of land for both farmers and herdsmen, given the subsistence nature of farming and the few numbers of cows that the herdsmen breed then, made them to co-exist peacefully, avoid of unhealthy competition over scarce resources. This type of relationships, even cordiality had usually played out between farmers and herdsmen in Nigeria until recently [Goke 2018].

However, conflicts between farmers and herdsmen emanated because of the growth in population, and respective increase in the need for more farmland. The conflict is reinforced by farmer's habit of extending the boundary in their farms to livestock path and the herdsmen's dependency of permitting cattle to veer into the farmer's farm to consume their flora and drop their dung either on the farm or at the pedestal course [Moritz 2010]. Thus, the farmersherdsmen incidents in Riyom of Plateau state, in Agatu of Benue state, in Nimbo of Enugu state and the alleged kidnapping of Chief Olu Falae (who is a farmer) by suspected herdsmen in Ondo state demonstrate a new dimension of the farmers-herdsmen conflict, as it has gone beyond the level of threats to individual lives and attained the level truly threatening national unity and integration ${ }^{1}$. The recent farmers-herdsmen attacks in Oke-Ogun area of Oyo state prove the trend. The re-incidence of communal conflicts have however persisted to cripple the country's integration efforts [Muhammed, Ismaila, Bibi 2015]. According to the available information, Northern Nigeria has recorded a more dose of communal conflicts than any other region [Muhammed, Ismaila, Bibi 2015]. The states where these conflicts have taken place are Benue, Nassarawa, Bauchi, Adamawa, Kaduna, Taraba, Kogi, etc... No doubt, communal

1 Oyeyipo S., James S., Sanda, J. The New Terror Threat // This Day. May 2, 2016. URL: https://www.thisdaylive.com/index.php/2016/05/02/thenew-terror-threat/ (accessed: 29.09.2019). 
conflicts have rendered these states unstable, hazardous and uninhabitable for effective social engagement and businesses [Aliyu, Ikedinma, Akinwande 2018]. A single attack by herdsmen on farmers on January 1st, 2018, in Benue state resulted in 73 victims, killed and buried in mass [Okoro 2018].

\section{Conceptual Clarification and the Research Problem Statement}

Farmers (agricultures) are individuals who involve in farming, raising raw materials or living organisms for food. The term therefore applies to people who do some combination of raising field orchards, poultry, crops, vineyards, or other livestock [Aliyu, Ikedinma, Akinwande 2018]. Based on this broad definition, farmers are both the herdsmen who herd or keep livestock like cattle, goats and sheep, and crop farmers. However, farmers are the crop farmers (those who raise field crops), also called peasant farmers / subsistence cultivators.

Before spreading into about 20 states throughout West Africa and the Sahel, as well as Western Sudan and the Central African Republic, the Fulani originated from Senegambia [Okoro 2018]. In Nigeria, the people are found in large numbers although, some have migrated into the towns, and many still live as semi-nomadic herders. However, these groups who own and rear livestock, such as cattle for commercial purposes, are called herdsmen.

Fulani pastoralists or Fulani herdsmen are nomadic or semi-nomadic herders whose primary occupation is livestock rearing [Okoro 2018]. In pursuit of pasture and fresh water, they typically move their herds from one location to another in search of fresh water and pasture, armed by machetes, arrows, daggers, etc. to defend their livestock. The troubling thing is that the herdsmen are blocking the highways with their animals, resort to robbing, kidnapping people and holding them captive.

The herder's background, expectations and interests are no doubt at variance with that of farmers in Nigeria. They are therefore to achieve their interests and expectations by attacking the peasant farmers in the course of grazing their herds. The causes for conflicts are different: control over land for grazing and farming, huge desertification of vegetative lands and droughts in Northern Nigeria which compel herders to migrate closer to the middle belt region and the south searching for greener pasture and water for their animals. In the course of their movement, the nomadic herdsmen settle in farming communities wherein there are green plants and water such as inside the Benue valley. In some instances, the farmers accuse the herdsmen of encroaching and destroying their farmlands and crops and contaminating their predominant supply of water. The herdsmen on their part accuse the farmers of poisoning, killing or even stealing their livestock especially cattle's and blocking of their grazing routes. The conflict has assumed worrisome dimension with the use of sophisticated weapons such as AK47 by the herdsmen who had used sticks and cutlasses while grazing.

Several farming communities in several states of Nigeria have suffered unrelenting attacks for some years. Regrettably, the conflict has even defied security measures by the Federal Government of Nigeria. Though the 1999 Constitution of the Federal Republic of Nigeria, as amended in Chapter II Section 14 Subsection 2 (b) states that 'the safety and welfare of the citizens will be the primary responsibility of the government'.

\section{Antecedents of Fulani Herdsmen-Farmers Conflict in Nigeria}

Fulani herdsmen and farmers clashes are dated to 2012. Before then, there has been peaceful relationship among farmers and herdsmen across the states in Nigeria, except few cases of minor misunderstandings that was not violent and took no life [Nzeh 2015; Doyin 2017].

On September 30, 2012, Mr. Benjamin Chegue, Director of Personnel Management, was killed in Isoko North Local Government Area of Delta state, and since then the spate of killings linked to farmers-herdsmen clashes had continued across the whole state.

In January 2013, Fulani herdsmen attacked some villages in Nasarawa state, killing ten 
women, with more than 5000 people displaced. In November 2014, around 33 people were killed in a new assault in few villages in Nasarawa state. According to the recent Global Terrorism Index, which listed African nations as the third most terrorized countries in the world, terrorists from the Fulani ethnic group are believed to have killed in 2014 at least 1229 people in Nigeria. Together with the Boko Haram terror group, the Fulani militants were responsible for more than 7000 deaths that occurred in Nigeria in 2014. Although Boko Haram predominates in Nigeria's terrorism-related headlines, little is known about the Fulani herdsmen's attacks and abductions [Ndubuisi 2018].

More Fulani armed herdsmen attacks took place in 2016 [Doyin 2017: 65]. Thus, in February 2016, 40 more people were killed as a result of a conflict between herdsmen and farmers in Benue state, about 2000 displaced and no less than 100 were seriously injured ${ }^{2}$. As result of the assault on Agatu Local Government Area of Benue state the Fulani herdsmen drove about 7000 people from six villages. The villagers complained that no military or security presence was felt, despite the heavy shooting by herdsmen. More than 200 people were killed and houses razed. In April 2016, the armed herdsmen carried out a renewed assault on Agatu with no less than 30 people dead [Ndubuisi 2018].

The southern Kaduna massacre in 2016 was another deadly attack, branded by some nongovernmental organizations as genocide against indigenous Southern Kaduna. The Catholic Archdiocese of Kafanch intimated that 808 lives were claimed and assisted by the unrest in southern Kaduna state. 53 villages so far were targeted and 57 people wounded ${ }^{3}$. As governor Nasir El Rufai declared the attackers were

${ }^{2}$ Duru P. 7000 Persons Displace in Fulani Herdsmen, Agatu Farmers Clash in Benue // Vanguard. February 29, 2016. URL: https://www.vanguardngr.com/2016/02/7000persons-displaced-in-fulani-herdsmen-agatu-farmers-clashin-benue/ (accessed: 29.09.2019).

3 Ajijah A. Church Says '808 Killed in Southern Kaduna' // Premium Times. December 29, 2016. URL: https://www.premiumtimesng.com/news/top-news/ 219173-church-says-808-killed-southern-kaduna.html (accessed: 29.09.2019). foreign herdsmen of the Fulani, who had avenged previous attacks on them and their cattle. Mr. Yakubu said that four local government areas had been targeted, killing 808 people and destroying 1422 homes, 16 churches, 19 shops and one primary school ${ }^{4}$. The Miyetti Allah Cattle Breeders Association, the herdsmen's umbrella body, states that due to the crisis in southern Kaduna it lost no less than 6000 cows [Uroko 2018: 7]. In 2017204 people were killed in the southern Kaduna crises according to the estimations of the National Emergency Management Agency ${ }^{5}$. The clashes in southern Kaduna between the Fulani herdsmen and local farmers lasted for months. More recently, in Benue and Nigerian states more than 92 Nigerians have been massacred by alleged Fulani herdsmen. Before this period, attacks by Fulani pastoralists in the southern states of the nation, including Enugu, Ekiti and Ondo States, were also recorded ${ }^{6}$.

\section{Causes of Farmers-Herdsmen Conflict}

Many factors are deemed responsible for the disputes between farmers and Fulani herdsmen in Nigeria. As Omawumi proclaims, the "current feud started because of farming, grazing land and water"7. The farmers accused the herdsmen of damaging their crops by failing to control their animals while the herdsmen equally claimed that the farming communities steal their cattle [Adeleke 2018]. In recent times, illegal invasion of farmland has led to severe conflicts between them due to the harm they have caused to crops and fallow land left to replenish nutrients after long years of use [Ahmed-Gamgum 2018]. Sometimes the herdsmen's cows wander into the farmland of the farmers without permission and

\section{${ }^{4}$ Ibid.}

5 Garba M. Nigerian Govt Says 204 Killed in Southern Kaduna Crisis // Premium Times. January 13, 2017. URL: https://www.premiumtimesng.com/news/ headlines/220353-nigerian-govt-says-204-killed-in-

southern-kaduna-crisis.html (accessed: 29.09.2019).

${ }^{6}$ Ibid.

7 Omawumi E. History of Fulani Herdsmen and Farmers Clashes in Nigeria // InfoGuide Nigeria. March 23, 2016. URL: https://infoguidenigeria.com/ fulani-herdsmen-farmers-clashes/ (accessed: 29.09.2019). 
kill crop nurseries or full-grown crops, which they hope will be harvested and sold. This kind of behaviour makes farmers to go after their animals, showing that the reduction in ecological space and resorts creates an environment of ecoscarcity that increases the stakes and places a premium on the resources available [Alozie 2019]. This leads to rather fierce competition and a desperate struggle for subsistence. Therefore, conflict becomes not only inevitable; it literally becomes a question of survival.

Climate change also contributes to the current dispute. The herdsmen would be forced to abandon their original dwelling to another place for greener pastures when there is an unfavourable weather. As Gleick describes, "Climate change has been tipped as the biggest single factor in causing migration and relocation of the population" [Gleick 2014]. According to the Intergovernmental Panel on Climate Change, this would impact people affected by shoreline erosion, coastal flooding, and agricultural destruction.

Expansion in farm production caused by encroachment of pastureland by farmers is also responsible for the conflict deepening. Initially not cultivated land was regarded as a potential pastureland. With the expansion in agriculture, the available pastureland has narrowed down thereby compelling the pastoralists to encroach into farmlands that were not supposed to be theirs. Where these basic needs of livelihoods of the pastoralists are not met either because of expanding land cultivation or desert encroachment, the pastoralists tend to move to some other places where they can have access to pastures [Clara 2017]. However, where they constitute more pressure to the available land resource, their presence is not always welcomed. This has been found to result into conflict with the settled people of the community.

Another reason for the incessant conflicts in the northern part of Nigeria is the ethnic-based approach towards land possession. Conroy [2014] opines that the Fulani's view land as a common resource which cannot be personalized, while the sedentary communities usually treat land as their exclusive preserve which no other community should encroach into.
Many scholars [Gefu, Kolawole 2002; Shettima, Tar 2008; Ofuoku, Isife 2009; Abbass 2012; Odoh, Chigozie 2012; Adisa 2012; Nformi, Mary-Juliet, Engwali, Nji 2014; Mwamfupe 2015; Doyin 2017] postulate that population explosion increases demand for food and respectively for farm produce. Hence this leads to more demand for land by the farmers to be able to meet the increasing food demand and to the encroachment of livestock route by the farmers in a bid to enlarge their farms for increase farm yields. The trampling of these supposed livestock routes, which are now other people's farms, intensified the conflict [Goke 2018; Akorede 2018].

Finally, the herdsmen's attacks in Nigeria in some way can be explained by the lack of political will of the government to properly arrest and prosecute criminals, as in the case of attacks in Nimbo in Uzo-Uwani Local Government Area and in Enugu city in 2016 [Okoro 2018]. The Fulani herdsmen attacked farmers in Nimbo because of the misunderstanding of the borders of the pasture fields, more than 50 people were killed and the property worth thousands of naira destroyed $^{8}$. There have been no serious arrests from that moment to the present, and the Fulani return at intervals to attack famers and villagers on their farms. Fulani herdsmen entered the farm a few months after the attacks in Nimbo and Enugu to feed their flocks, and while they were doing so, the owners of the farmland came and chased them and their cattle away. The Fulani herdsmen came to this sequel at midnight and attacked the people, killing a pregnant woman [Ajibefun 2018].

\section{Farmers-Herdsmen Conflict: Effect on National Unity}

The farmers-herdsmen conflict adversely affects Nigeria's national unity which has been built since independence. It could be assured by firmly pursuing integration which would create

8 Mamah E., Ndujihe C., Nkwopara C., Ozor C. Bloodbath in Enugu as Fulani Herdsmen Kill 40 // Vanguard. April 26, 2016. URL: https://www.vanguardngr. com/2016/04/bloodbath-enugu-fulani-herdsmen-kill-40/ (accessed: 29.09.2019). 
the feeling of peace and solidarity. According to Oyedotun, national integration is presented as a mechanism that leads to political stability and sentiments of loyalty to central political institutions ${ }^{9}$. In their research on the assessment of the farmers-herdsmen conflicts on national integration Aliyu, Ikedinma, and Akinwande state that "national integration is the process of unifying a society that tends to make its harmonious city, based on an order that its members consider to be equitably harmonious" [Aliyu, Ikedinma, Akinwande 2018]. They view national integration as "the attainment, within a territory of a sense of community and of institutions and practices strong enough and widespread enough to assure, for a long time dependable expectations of peaceful community" [Aliyu, Ikedinma, Akinwande 2018].

Meanwhile some state governors have been cited as preaching the opposite - disintegration of Nigeria. For example, the Ekiti state governor, Mr. Ayodele Fayose, was allegedly accused of inciting comments capable of affecting the integration of various tribes in the country. $\mathrm{He}$ announced that farmers in his state should start using any means to defend themselves from militants Fulani herdsmen ${ }^{10}$. Many have misunderstood him as his instructions were calling on the farmers to take laws into their hands. In the same vein, Samuel Ortom, the Benue state governor, directed Fulani herdsmen within two days to leave Tombo-Mbalagh in the Buruku Local Government Area. He has directed security officers to force herdsmen out of the community [Aliyu, Ikedinma, Akinwande 2018]. His defection from the opposition Peoples Democratic Party was connected similarly to the federal government's alleged defense of herders. In early 2018, the president publicly urged individuals from the state of Benue to learn to tolerate others. The declaration by the president also appeared as a flame to the already tense situation in Benue State [Aliyu, Ikedinma, Akinwande 2018]. Some Nigerians qualified it as

\footnotetext{
9 Oyedotun W. New Dimensions to the Killings of Farmers in Nigeria // Tribune Editorial. April 26, 2017.

${ }^{10}$ Governor Ortom orders herdsmen to leave Benue Community // The News. March 29, 2017.
}

taking sides. It will take time to see if the Fulani in the northern parts of the country will not evict other tribes residing among them equally, as there has been friction within the community. The Council of State also called on President Muhammadu Buhari to urgently resolve the conflicts between farmers and herdsmen because of their threat to national unity. It is a big concern now threatening Nigeria's unity after almost sixty years of independence [Alozie 2019].

Aside the general effects on loss of lives, animals, farm crops, there are soil erosion, poisoning of water and displacement of farmers and pastoral problems. Okoli and Atelhe [2014]; Odoh and Chigozie [2012] reported that 700 to 2000 pastoralists were expelled by the local authorities in Borno and Plateau states respectively. Thus, the minority question has been escalated. The Fulani tribe in most communities declares itself as the minority. Thereby, it claims that their rights to land (which they consider to equally own with the sedentary groups or initial settlers) access is denied by the sedentary groups. It also blames government for not providing enough support, but rather alienating them from their sources of livelihood. The crisis is now snowballing into tribal and religious clashes as witnessed in Southern Kaduna, where Christians were killed by Muslims, which was occasioned by farmersherdsmen conflict [Aliyu, Ikedinma, Akinwande 2018]. The killings are still on and represent a true threat to national integration. There is usually counterattack in entirely unaffected places in reaction to the loss suffered in farmersherdsmen clashes elsewhere. The killings of four herdsmen and dumping of their bodies into Ifu River on January 21, 2020 is a retaliatory attack, committed by youths of Oforachi community in Idah Local Government Area (LGA) Kogi state. The attack was made in response to the killing of the 65-year-old Godwin Egbunu in his farmland.

Conflict between farmers and herdsmen has the greatest potential to eradicate the source of livelihood as it currently aggravates the food crisis and its high costs. This happens when cattle hooves compress the farm's soil making it less efficient for farmers and even when the 
cattle are killing crops [Adisa, Adekunle 2010]. In the face of the increasing population's predominant disproportionate increase in food production, farmers-herdsmen have further exacerbated food security as many farmers leave the farms for fear of being mutilated or killed. Many of them shift in the process to urban centres in search of alternative means of subsistence. In doing so, they not only intensify the burden on the city's infrastructure but also remain unemployed. They have become prone instruments for perpetuating abuse and crime in society [Audu 2013].

Thus, the farmers-herdsmen conflict is now said to be of co-extensiveness (cover the same area or range) with religious and culture conflicts. This is because most farmers tend to be of the same ethnic group and mostly Christians especially in the middle belt region of Nigeria, while most pastoralists are Fulani and predominantly Muslims [Ahmed-Gamgum 2018]. In an event of a conflict between these groups, they are easily perceived as ethnic or religious conflicts because of their closeness in such lines. 2010 Jos crisis between the Hausa residents and the settlers in the area demonstrates the case. The aggression on the Hausa was easily transferred to the Fulani because it was perceived that they belong to the same religion. This misrepresentation was partly responsible for the Southern Kaduna crisis, where scores of Christians [Ahmed-Gamgum 2018] were gruesomely murdered and many churches burnt down.

\section{Conclusion}

Disputes between farmers and herdsmen are disruptive and will have far-reaching consequences for Nigeria's national unity if left unchecked quickly. These disputes inevitably destroy resources and are capable of making different tribes to be at dagger draw with each other. It therefore calls for quick intervention from the nation's leadership. Given the incidents, causes and effects of farmers-herdsmen conflicts on national integration as earlier exemplified, the following recommendations could be put ahead:

- Offensive terms in policies and laws such as cattle colonies and anti-open grazing should be replaced.

- Value re-orientation strategy should be largely promoted to motivate Nigerians to appreciate the values that unite them more than those that divide them. Tolerance for other ethnic groups should be encouraged.

- Formulation and execution of government policies should not be taken to favour a group of people or tribe against another. As in the current case of support by the federal government towards the Fulani herdsmen.

- Alternative Dispute Resolution (ADR) could be introduced in resolving farmersherdsmen conflicts instead of resorting to court settlement. This kind of conflict resolution can be enshrined into the country's national policies. For the ADR strategy to be effective, more powers have to be devolved to the local level and empower the local chiefs and traditional rulers. Local governments should collaborate in various ways to forestall occurrence of farmersherdsmen conflicts. One of these ways of collaboration is the registration of immigrant herdsmen in their localities.

- Herdsmen and farmers should avoid making speeches of hate, as they inspire resentment and break unity.

- Members of the host communities and Fulani herdsmen should be communicated to the public forum and be involved in the decisionmaking process and allowed to engage effectively in the planning procedure for restoring peace to the majority of the communities concerned.

Received / Поступила в редакцию: 23.08.2020 Accepted / Принята к публикации: 12.10.2020 


\section{References / Библиографический список}

Abbass, I.M. (2014). No Retreat No Surrender Conflict for Survival between Fulani Pastoralists and Farmers in Northern Nigeria. European Scientific Journal, 8 (1), 331-346. URL: https://eujournal.org/index.php/esj/ article/view/4618 (accessed: 12.07.2020).

Adeleke, M. (2018). The Increasing Spate of Killings in Nigeria: Cases, Causes and the Needful. African Development, 2 (2), $32-45$.

Adisa, R.S. \& Adekunle, O.A. (2010). Farmer-Herdsmen Conflicts: A Factor Analysis of Socio-economic Conflict Variables among Arable Crop Farmers in North Central Nigeria. Journal of Human Ecology, 30 (1), 1 -9. DOI: $10.1080 / 09709274.2010 .11906266$

Adisa, R.S. (2012). Land Use Conflict between Farmers and Herdsmen - Implications for Agricultural and Rural Development in Nigeria. In: Adisa, R.S. (Eds.). Rural Development: Contemporary Issues and Practices. London: IntechOpen. P. 99-118. DOI: 10.5772/45787

Ahmed-Gamgum, W.A. (2018). Herdsmen and Farmers Conflict in Nigeria: Another Dimension of Insecurity. Journal of Public Administration and Social Welfare Research, 3, 35-62.

Ajibefun, M.B. (2018). Social and Economic Effects of the Menace of Fulani Herdsmen Crises in Nigeria. Journal of Educational and Social Research, 8, 133-139. DOI: 10.2478/jesr-2018-0024

Akorede, O.P. (2018). Implications of Farmers-Herdsmen Conflicts on Nigeria's Cohesion. Journal of Multidisciplinary Studies, 7 (3), 22-45.

Aliyu, M.K., Ikedinma, H.A. \& Akinwande, A.E. (2018). Assessment of the Effect of Farmers-Herdsmen Conflicts on National Integration in Nigeria. International Journal of Humanities and Social Sciences, 8 (10), 118-128. DOI: $10.30845 /$ ijhss.v8n10p13

Alozie, C.C. (2019). Communal Conflicts and Challenges of National Integration in Nigeria in the 21 st Century. International Journal of Social \& Management Sciences, 2 (1), 39-50. URL: https://www.zeetarz.com/ijsms/ wp-content/uploads/2019/01/The-Poverty-Syndrome-and-the-Challenges-of-National-Development-inContemporary-Nigeria.pdf (accessed: 23.07.2020).

Audu, S.D. (2013). Conflicts among Farmers and Pastoralists in Northern Nigeria Induced by Freshwater Scarcity. Developing Country Studies, 3 (12), 25-32.

Clara, T.V. (2017). Insecurity, Loss of Lives and Policy Issues in Nigeria. African Affairs, 4 (2), 67-79.

Conroy, S. (2014). Land Conflicts and Lethal Violence in Nigeria: Patterns, Mapping and Evolution (2006-2014). IFRA-Nigeria Working Papers Series, 38, 1-38.

Doyin, T. (2017). An Empirical Investigation to Incessant Killings in Nigeria. Journal of Philosophy, 5, 67-82.

Gefu, J.O. \& Kolawole, A. (2002). Conflict in Common Property Resource Use: Experiences from an Irrigation Project. The Commons in an Age of Globalisation: The Ninth Biennial Conference of the International Association for the Study of Common Property. Victoria Falls, Zimbabwe. June 17-21. URL: https://dlc.dlib.indiana.edu/dlc/bitstream/handle/10535/1034/gefuj080502.pdf? sequence=1\&isAllowed=y (accessed: 17.07.2020).

Gleick, P.H. (2014). Water, Drought, Climate Change, and Conflict in Syria. Weather, Climate, and Society (WCAS), 6 (3), 331-340. DOI: 10.1175/WCAS-D-13-00059.1

Goke, S. (2018). The Genesis of Farmers-Herdsmen Clashes in Nigeria. Journal of Social Sciences, 4 (2), 34 - 48.

Moritz, M. (2010). Understanding Herder-Farmer Conflicts in West Africa: Outline of a Processual Approach. Human Organization, 69 (2), 138-148.

Muhammed, I., Ismaila, A.B. \& Bibi, U.M. (2015). An Assessment of Farmer-Pastoralist Conflict in Nigeria Using GIS. International Journal of Engineering Science Invention, 4 (7), 23-33.

Mwamfupe, D. (2015). Persistence of Farmer-Herder Conflicts in Tanzania. International Journal of Scientific and Research Publications, 5 (2), $1-8$.

Ndubuisi, C.I. (2018). A Critical Analysis of Conflicts between Herdsmen and Farmers in Nigeria: Causes and Socioreligious and Political Effects on National Development. HTS Teologiese Studies / Theological Studies, 74 (1), 1—6. DOI: 10.4102/hts.v74i1.5065

Nformi, M.I., Mary-Juliet, B., Engwali, F.D. \& Nji, A. (2014). Effects of Farmer-Grazer Conflicts on Rural Development: A Socio-economic Analysis. Scholarly Journal of Agricultural Science, 4 (3), 113-120. URL: http://www.scholarly-journals.com/sjas/archive/2014/March/pdf/Nformi\%20et\%20al.pdf (accessed: $07.06 .2020)$.

Nzeh, E. (2015). The Effects of Migration by Nomadic Farmers in the Livelihoods of Rural Crop Farmers in Enugu State, Nigeria. Global Journal of Science Frontier Research, 15 (3), 45-56. 
Odoh, S.I. \& Chigozie, C.F. (2012). Climate Change and Conflict in Nigeria: A Theoretical and Empirical Examination of the Worsening Incidence of Conflict between Fulani Herdsmen and Farmers in Northern Nigeria. Arabian Journal of Business and Management Review, 2 (1), 110-124.

Ofuoku, A.U. \& Isife, B.I. (2009). Causes, Effects and Resolution of Farmers-Nomadic Cattle Herders Conflict in Delta State, Nigeria. International Journal of Sociology and Anthropology, 1 (2), 47-54. URL: https://academicjournals.org/journal/IJSA/article-full-text-pdf/181F8D9696 (accessed: 17.07.2020).

Okoli, A.C. \& Atelhe, G.A. (2014). Nomads against Natives: A Political Ecology of Herder / Farmer Conflicts in Nasarawa State, Nigeria. American International Journal of Contemporary Research, 4 (2), 76-88.

Okoro, J.P. (2018). Herdsmen / Farmers Conflict and Its Effects on Socio-Economic Development in Nigeria. Journal of Peace, Security, and Development, 4 (1), 143-158.

Shettima, A.G. \& Tar, U.A. (2008). Farmer-Pastoralist Conflict in West Africa: Exploring the Causes and Consequences. Information, Society and Justice, 1 (2), 163-184.

Uroko, F.C. (2018). The Ethno-Religious Conflicts in Southern Kaduna of Nigeria: Causes and Implication for National Development. Afro Asian Journal of Social Sciences, 9 (2), 1-12. URL: http://www.onlineresearchjournals.com/aajoss/art/280.pdf (accessed: 17.07.2020).

\begin{abstract}
About the authors: Oghuvbu Ejiroghene Augustine - Assistant Lecturer, Department of Political Science and International Relations, College of Leadership and Development Studies, Covenant University, Ota, Ogun State, Nigeria (e-mail: augustine4best@yahoo.com).

Oghuvbu Oluwatobi Blessing - PhD Candidate, Department of Library and Information Science, Faculty of Education Delta State University, Abraka, Nigeria (e-mail: bfamuti@gmail.com).
\end{abstract}

Сведения об авторах: Огувбу Эджирогене Августин - ассистент кафедры политологии и международных отношений, Колледж лидерства и исследования проблем развития, Университет Ковенант, Ота, штат Огун, Нигерия (e-mail: augustine4best@yahoo.com).

Огувбу Олуватоби Блессинг - аспирант кафедры библиотечного дела и информатики, педагогический факультет Государственного университета Дельты, Абрака, штат Дельта, Нигерия (e-mail: bfamuti@gmail.com). 